PAPERS READ.

\title{
ON THE SUPPOSED NEW ZEALAND SPECIES OF LEPTOPOMA.
}

\author{
By O. F. von Moellendorff, Ph.D.
}

\section{(Communicated by C. Hedley.)}

Mr. H. Suter sent me a few examples of the so-called Leptopoma species of New Zealand, expressing some doubts on the systematic position hitherto assigned to them, and asking my opinion on the subject, as he himself was in want of the necessary literature and specimens for comparison, whilst he supposed that I, living in the centre of distribution of the Cyclophorida, viz., Eastern Asia, should have more experience in the study of operculate pulmonata. Mr. Suter points out the evident relation of these shells with Cyclophorus cytora, Gray, and proposes they should form, together with that species, a separate subgenus of Cyclophorus.

The study of the rather scant material before me and the comparison of the numerous small cyclophoroid forms of Eastern Asia and Indonesia have led me to the conclusion that the New Zealand species in question belong to Lagochilus, Blfd. The operculum is certainly that of Cyclophorus, Lagochilus or Leptopoma, there existing but minute differences in this respect between the three genera. Likewise the dentition and the outer aspect of the animal as described by Prof. Hutton correspond perfectly with that of the subfamily of Cyclophorince. The conical shape, the small size, the thin but opaque and scarcely transparent shell, its nore or less dark colour, the peculiar structure of the cuticula, forming thin, deciduous ribs occasionally produced into membranaceous processes or fimbrice, the angle formed by the upper margin of the peristome at its insertion, all decidedly point to 
Lagochilus. The chief peculiarity of that genus, expressed by its name, viz., a slit or incision in the upper lip at its insertion, is formed by the margins, or rather the upper margin and the parietal callosity, meeting in an angle and is of course distinctly visible only in those species which have a thickened lip and connected margins, but there are many recognised species of Lagochilus with a thin lip and remote margins in which the abovementioned formation is only represented by the angular insertion of the upper margin. Of the New Zealand species Lagochilus cytora, Gray, belongs to the first group, having a double lip and continuous peristome and showing a distinct slit or groove at the upper angle of the aperture, whilst $L$. pannosum, Hutt., calvum, Hutt., pallidum, Hutt., and the new species, L. torquillum, Suter, are formed in the latter way.

The question whether my classification is correct or not can only be decided with certainty by the examination of the animals, as Lagochilus is characterised by a glandular slit in the extremity of the foot. Judging, however, from the shells alone, I have very little doubt that the species in question belong to Lagochilus. They differ from the species known to me by the absence of elevated spiral lines or keels and by the more conically elevated, almost pyramidate shape, but I do not think it necessary to create a special section for them, at least not before the geographical distribution of Lagochilus is more fully known. The genus ranges from India and China to the Philippines, the Malayan Archipelago and New Guinea (L. triliratum, Pfr., poirierii, Tapp.-Can., and perhaps also rugatellum, Tapp.-Can., described as Cyclotus). I am all but sure that Cyclophorus liricinctus, Bens., and C. orbiculatus, Bens., from Western Australia, both of which are described with " apertura superne angulata," the latter besides "subcanaliculata," belong to our genus. Cyclophorus whitei, Braz., of Fitzroy Island, might also be a Lagochilus, but possibly as well a Ditropis, as Brazier contends. The genus may yet be discovered on the Melanesian islands; Cyclophorus fornicatus, Pfr., from the New Hebrides, I feel inclined to consider a representative of Lagochilus. 


\section{$2 \mathrm{BHL}$ Biodiversity Heritage Library}

Möllendorff, Otto Franz von. 1893. "On the supposed New Zealand species of Leptopoma." Proceedings of the Linnean Society of New South Wales 7, 385-386. https://doi.org/10.5962/bhl.part.26063.

View This Item Online: https://www.biodiversitylibrary.org/item/29776

DOI: https://doi.org/10.5962/bhl.part.26063

Permalink: https://www.biodiversitylibrary.org/partpdf/26063

\section{Holding Institution}

MBLWHOI Library

\section{Sponsored by}

MBLWHOI Library

\section{Copyright \& Reuse}

Copyright Status: NOT_IN_COPYRIGHT

This document was created from content at the Biodiversity Heritage Library, the world's largest open access digital library for biodiversity literature and archives. Visit BHL at https://www.biodiversitylibrary.org. 